\title{
Corporate Social Performance and the Likelihood of Bankruptcy: Evidence from a Period of Economic Upswing
}

\author{
Florian Habermann $^{1}$ (D) Felix Bernhard Fischer ${ }^{1}$ iD
}

Received: 1 June 2021 / Accepted: 20 September 2021 / Published online: 4 October 2021

(C) The Author(s) 2021

\begin{abstract}
The paper aims to investigate the effects of corporate social performance (CSP) on bankruptcy likelihood in times of economic upswing. This is important because prior related literature focused on data containing times of economic crises. We measure bankruptcy likelihood with the Altman Z score and CSP with Refinitiv ESG scores. By applying static panel data regressions and instrumental variable regressions on a sample of 6696 US-firm-year observations from 2010 to 2019 our main findings are: (i) In contrast to existing research, the level of firms' CSP seems to have no (positive) effect on the likelihood of bankruptcy during times of economic upswing. (ii) Increasing a firm's CSP in times of economic upswing leads to a rise in bankruptcy likelihood. We conclude that the positive effects of CSP on stakeholder relationships fail to materialize in flourishing business environments. The costs of increasing CSP, thus, exceed their immediate positive effects and raise bankruptcy likelihood. However, as they reduce financial default risk in subsequent crises, CSP investments can be seen as a balancing measure. Our findings bear implications for scholars, practitioners, and policymakers.
\end{abstract}

Keywords Corporate social performance $\cdot$ Bankruptcy $\cdot$ ESG ratings $\cdot$ Altman $Z$ score $\cdot$ Stakeholder theory $\cdot$ Corporate financial performance

JEL Classification G30 $\cdot \mathrm{G} 33 \cdot \mathrm{G} 34 \cdot \mathrm{M} 14$

\section{Introduction}

For several years, sustainability and the concept of corporate social responsibility has received growing attention in society. As a result, firms face increasing pressure to conduct their business sustainably, i.e., to increase their corporate social performance (CSP) (Baldini et al., 2018). For instance, in 2020, institutional investors publicly accused supervisory boards of failing to address environmental, social, and governance (ESG) issues sufficiently, i.e., to increase CSP (Köhler \& Landgraf, 2020). Furthermore, they attested firms to pursue inadequate risk assessment around those issues (Mooney et al., 2020). Thus, these investors

Florian Habermann

florian.habermann@ku.de

Felix Bernhard Fischer

felix.fischer@ku.de

$1 \quad$ Ingolstadt School of Management, Catholic University Eichstätt - Ingolstadt, Auf der Schanz 49, 85049 Ingolstadt, Germany assume that low CSP connects to firm risk. If this holds true, firms neglecting ESG topics face a higher financial distress risk and, therefore, a higher bankruptcy likelihood (BL). For this reason, we investigate whether a sustainable way of doing business or - in other words - investment in ESG endeavors (i.e., increasing CSP) connects to the likelihood of bankruptcy.

While numerous studies observed CSP from an angle of financial success (Friede et al., 2015), there has been only scant research on the association between CSP and bankruptcy, i.e., financial failure. In this strand of literature, most studies have focused on the effect of CSP related to negative events. Such an event can be linked to the firm (Godfrey et al., 2009, competitive events and stakeholder-based negative events), social responsibility crises (Blacconiere \& Patten, 1994, e.g., Bhopal catastrophe; Lins et al., 2017, e.g., Enron/Worldcom crisis), or other exogenous events affecting the whole economy such as the global financial crisis in 2008 (Kemper \& Martin, 2010; Lins et al., 2017). Even fewer studies examined the relationship between CSP and the likelihood of bankruptcy. In a recent study, Cooper 
and Uzun (2019) applied a potential approach to do so. They compared 78 US firms that filed for Chapter $11^{1}$ with matched counterparts (i.e., similar firms that did not file for Chapter 11) during the period 2007 to 2014. Besides, Boubaker et al. (2020) used a more robust sample of 1,201 USlisted firms and the Altman $Z$ score ( $Z$ score) as a proxy for financial distress risk (FDR), during 1991-2012. In this vein, Lin and Dong (2018) applied a logistic regression model incorporating observations between 2000 and 2014. All three studies show positive effects of CSP on BL.

However, while the data of each study includes at least one big economic crisis, the present study examines the effect of CSP on BL during a period of economic upswing. The need to conduct such a study arises since CSP tends to show different effects in different stages of an economic cycle and, consequently, may bias the previously mentioned studies. For instance, Lins et al. (2017) show that high CSP led to higher stock returns, profitability, growth, and sales per employee during the global financial crisis for the years 2008 and 2009. Moreover, Ducassy (2013) has found a positive effect of CSP on corporate financial performance (CFP) at the beginning of the financial crisis in 2007, while the effect disappeared after the first 6 months of the crisis. In this vein, two recent studies highlight the heterogeneous effect of CSP on firm risk during crises and "normal" times (Bouslah et al., 2018; Broadstock et al., 2021). The authors provide evidence that the positive effect of CSP is high in times of crisis but diminishes in importance afterwards. Consequently, since no study so far has examined the effect of CSP on BL in times of economic prosperity, we address this gap in literature by conducting this study.

For this reason, we use a panel dataset from Thomson Reuters (TR) Eikon containing 6696 observations of large US-listed firms during the period 2010 to 2019. We measure CSP with Refinitiv ESG scores. Since Refinitiv rates firms overall and in the respective ESG pillar, we are able to follow current studies (e.g., Dyck et al., 2019; Ferrell et al., 2016) and investigate the relationship on a more granular basis. The main dependent variable for predicting the likelihood of bankruptcy is the $Z$ score. By applying this metric, we gain two advantages. First, we apply a high-quality measure for future BL (Altman, 1968; Altman et al., 2017). Second, since the $Z$ score is available for many publicly listed firms, we employ a robust sample as conducted in Boubaker et al. (2020). In contrast to that study, we use Refinitiv ESG scores to investigate the relationship between bankruptcy and CSP.

\footnotetext{
$\overline{1}$ Chapter 11 of the US bankruptcy code allows a firm in distress to reorganize and to resolve its distress within a bankruptcy process by temporarily providing protection from its creditors and measures to negotiate with them; see, e.g., Nigam and Boughanmi (2017).
}

We introduce and address the advantages of Refinitiv ESG scores in the further course of the paper.

Our main results of fixed effects panel data regressions are twofold: First, we find evidence that during times of economic growth, the CSP level does not affect the $Z$ score, i.e., the likelihood of bankruptcy (except for a negative effect in the governance pillar). Second, increasing the CSP level during times of upswing lowers the $Z$ score, i.e., inflates $B L$. The main driver for this effect can be attributed to the social pillar. This is in line with our hypothesis suggesting that investing in stakeholder relationships may not pay off in a flourishing economic environment as distressed firms do not rely on loyal stakeholders to resolve their distress during such times. To address endogeneity and consequently strengthen the reliability of our findings, we conduct several robustness tests, amongst them an instrumental variable approach. In addition, we test the CSP-BL relationship for times of crisis (i.e., the financial crisis; period from 2007 to 2009) and find that a higher level of overall CSP, environmental, and social performance decreases BL. Consequently, the robustness tests results support the results of the existing studies on times of downturn (in particular, Boubaker et al., 2020; Cooper \& Uzun, 2019) and strenghten our findings for times of upswing.

We contribute to the existing literature as follows. First, we provide novel insights on the CSP-CFP relationship by focusing on times of economic upswing and using $\mathrm{BL}$ as an indicator for financial failure. Second, in contrast to prior research (Boubaker et al., 2020; Cooper \& Uzun, 2019), the present study is the first to show that in times of upswing, increasing CSP does not mitigate BL but rather increases it. However, we are able to fit our results into the context of the existing literature: While in tough economic times, a high CSP level reduces BL due to increased support from stakeholders, these effects diminish in the beneficial environment of an upswing. Hence, the positive effects of CSP cannot compensate the costly CSP investments in "good" times; however, they may mitigate financial default risk in subsequent crises. Third, as prior studies only addressed bankrupt firms (which results in a small sample size, e.g., Cooper \& Uzun, 2019) or applied factorial variables for CSP (e.g., Boubaker et al., 2020; Lin \& Dong, 2018), we provide novel insights by using a representative and robust sample of 6696 firm-year observations. Refinitiv ESG scores have been used as a continuous CSP measure in panel data and instrumental variable regressions as conducted in Cheng et al. (2014) as well as Aouadi and Marsat (2018). Finally, this study opens up space for further research in the CSP-bankruptcy literature. We provide novel insights on stakeholder theory in the context of economic conditions but also point inter alia to institutionalization theory as an alternative approach to be examined in future research. Furthermore, as we differentiate between the effects of the individual ESG pillars and 
consider firm size and FDR, we offer researchers a starting point for investigating particular effects of CSP.

The remainder of this paper is structured as follows. In the "Literature Review, Theory, and Hypothesis Development" section, we provide a literature review of how corporate sustainability can affect BL. Furthermore, we develop our research hypotheses. In the "Data and Methodology" section, we present the data and introduce the applied research methodology. The "Results" section shows the results of the empirical analyses. In the "Robustness Tests" section, we conduct several robustness tests to address endogeneity. We discuss the implications of the results in the "Discussion" section and conclude the paper in the "Conclusion" section.

\section{Literature Review, Theory, and Hypothesis Development}

\section{Related Literature}

As described in the introduction, numerous studies have observed CSP from an angle of financial success. However, there is only scant literature examining the effect of CSP on financial failure, i.e., the likelihood of bankruptcy. When considering financial success, there are two main rival theories $^{2}$ explaining the effects of CSP on CFP: shareholder and stakeholder theory. First, shareholder theory was established in the middle of the twentieth century and culminated in the 1970 article "The Social Responsibility of Business Is to Increase Its Profits" by Milton Friedman (Flammer, 2015; Friedman, 1970). According to this theory, ESG investments are considered as additional costs and harmful for shareholders. As a result, CSP lowers CFP. In this context, agency theory offers an explanation why firms nonetheless engage in CSP: Managers (i.e., agents) might promote a firm's social engagement contrary to shareholders' (i.e., principals) interests and CFP because of the pressure of non-invested outsiders. Besides, managers may act socially responsible due to their preferences or for personal benefits (Dyck et al., 2019; Ferrell et al., 2016; Jensen \& Meckling, 1976). In contrast to that, stakeholder theory argues that the interests of numerous parties, such as customers, suppliers, employees, or creditors, are essential for a firm to prosper (Freeman, 1984).

Empirical results support both of these rival theories. While many studies pronounce the value-enhancing effect of CSP (Friede et al., 2015; Margolis \& Walsh, 2003), some studies indicate negative (Orlitzky, 2015; Zhao \& Murrell,

\footnotetext{
${ }^{2}$ Current literature provides additional theories (e.g., signaling theory) for the CSP-CFP relationship. However, a holistic discussion of all these theories is beyond the scope of this paper.
}

2016) or neutral effects (Garcia-Castro et al., 2010). Methodological concerns, such as variable selection or model misspecifications, might be responsible for these inconclusive findings (Flammer, 2015; Servaes \& Tamayo, 2013). In sum, studies providing evidence for a positive effect of CSP on CFP outweigh the studies reporting neutral or negative effects (Friede et al., 2015). Vishwanathan et al. (2020) provide four value-creating mechanisms of CSP to explain this positive effect: enhancing firm reputation, increasing stakeholder reciprocation, mitigating firm risk, and strengthening innovation capacity.

Turning to financial distress, one strand of literature examines the role of corporate governance and the likelihood of bankruptcy. In particular, the existing research focuses on the effects of board characteristics (Darrat et al., 2016; Fich \& Slezak, 2008; Platt \& Platt, 2012) and ownership (Parker et al., 2002; Robinson et al., 2012). However, other studies emphasize that the governance pillar plays a different role compared to the other ESG pillars (Fabrizi et al., 2014; Kim et al., 2012; Lin \& Dong, 2018), e.g., as many governance measures are being used without the intention to increase CSP. For this reason, the respective authors did not consider the governance pillar in their research. We aim to solve this challenge by investigating and interpreting the results from each pillar separately.

Another strand of literature focuses on the effects of management and leadership (i.e., aspects of the social and governance pillar of ESG) as a measure in ongoing distress situations. Sudarsanam and Lai (2001) as well as Jostarndt and Sautner (2008) suggest that top management change is an essential measure in turnaround situations. This is in line with the findings of Bogan and Sandler (2012); the authors state that management change is the most important success factor in Chapter 11 bankruptcy processes. Furthermore, Meyer (2004) highlights the importance of leadership and communication skills (i.e., stakeholder management) in situations of strategic change. Accordingly, successful management change to resolve distress (i.e., to reduce $\mathrm{BL}$ ) connects to social factors as managers motivate employees and strengthen the trust of stakeholders. However, there is little research on how a holistic approach considering all three ESG pillars affects the likelihood of bankruptcy.

As described in the introduction, some studies focus on CSP and the occurrence of negative events, but few studies examine CSP and BL. Three current studies investigated the topic but used data that includes periods of economic crises. First, Lin and Dong (2018) used the $Z$ score to identify financially distressed firms and conduct logistic regressions to examine how CSP affects BL. Second, Cooper and Uzun (2019) studied whether CSR efforts reduce the probability of going bankrupt by applying t-tests and logistic regression on a matched sample of bankrupt and comparable non-bankrupt firms. Both studies show that higher CSP leads to lower BL. 
Finally, Boubaker et al. (2020) assessed the level of FDR, including CSP measures. The authors applied three different proxies for FDR ( $Z$ score, O score, and ZM score; for a detailed description see Boubaker et al., 2020) and show that higher CSP lowers BL, regardless of the proxy they apply. Consequently, CSP seems to have positive effects on BL when observing periods including economic downturn or turmoil.

In this context, it is necessary to define economic upswing and downturn for this study. Economic or business cycle theory is a topic discussed from many perspectives in economics over several decades (see, e.g., Lucas, 1980; McGrattan \& Prescott, 2014). For the scope of this paper, we settle for the definition of the National Bureau of Economic Research (NBER). According to the NBER, an economy is normally in the state of expansion (upswing), but faces phases of recession (downturn) measured as times between a peak and lowest point. Economic activity can be tracked with the gross domestic product. In a recession, unemployment is higher, while income and aggregate demand are lower than in expansion times (NBER, 2021).

\section{Hypothesis Development}

Bankruptcy occurs when a firm in financial distress is unable to meet its obligations (i.e., to repay its due liabilities) and, as a result, enters a collective proceeding. The proceeding aims to settle the competing claims of the firm's creditors (Baird, 1987). Financial distress is caused by internal failure (i.e., poor management), industry decline, or economic distress (Wruck, 1990), such as the global financial crisis or COVID19-pandemic. In the context of economic conditions or cycles, this means that in times of economic upswing, fewer firms (i.e., only firms showing internal failure or industry decline) should face problems concerning bankruptcy while in times of economic crisis, many firms face problems due to external causes.

While a firm is unable to influence external causes, its management can reduce the likelihood of bankruptcy by conducting countermeasures at an early stage of distress (Whitaker, 1999). In other words, transparent internal structures (i.e., governance) may enable the management to detect emerging distress at an early stage and resolve it without entering a formal bankruptcy process. Furthermore, in line with the value-creating mechanisms of stakeholder theory, high CSP may increase the feasibility of countermeasures, e.g., due to higher stakeholder reciprocation and innovation capacities. Particularly, the mechanism of improved key stakeholder engagement connects FDR with CSP (Boubaker et al., 2020). CSP might reduce BL through positive effects in each of the three ESG pillars: (i) Investments in environmental measures (i.e., in more sustainable supply and value chains) should reduce BL as they improve environmental firm performance and, thus, reduce the risk of losing reputation (Liang \& Renneboog, 2017). Furthermore, investments in sustainability might increase the resilience of supply chains due to more loyal and reliable stakeholders, especially suppliers (Hofmann et al., 2018; Vishwanathan et al., 2020), fostering stability when dealing with emerging distress. (ii) Consistent investments in social measures increase the motivation and collaboration of employees, management, and other stakeholders (De Roeck et al., 2016; Edmans, 2011; Scheidler et al., 2019). On the one hand, these investments might decrease the firm risk of internal failure due to higher management motivation and social awareness. On the other hand, highly motivated employees and other stakeholders (such as customers and suppliers) should act more loyal and innovative (Flammer \& Kacperczyk, 2016; Vishwanathan et al., 2020) when dealing with emerging distress. As a result, a socially responsible firm may exhibit a higher probability to resolve distress without filing for bankruptcy. (iii) Improving internal governance structures tends to increase transparency (i.e., reduce information asymmetry) and enables to detect potential distress situations at an early stage (Cheng et al., 2014). Besides, such structures can decrease the possibility of poor and short-term-oriented management (i.e., firm risk; see, e.g., Vishwanathan et al., 2020) leading to distress. Moreover, transparent structures (with the meaning of communication and cooperation) may foster mutual trust to/of stakeholders (e.g., banks) and, thus, improve high CSP firms' access to financing (El Ghoul et al., 2017; Lee \& Faff, 2009).

However, in times of economic upswing, firms may prevent filing for bankruptcy irrespective of their CSP level: A small number of firms in distress coincides with high aggregate demand and credit supply compared to a downturn. Consequently, we argue that firms in distress do not depend on loyal stakeholders, such as creditors, suppliers, and customers, helping to resolve the distress as there simply are many stakeholders around willing to lend and spend money. Therefore, positive effects of CSP on BL might only appear in times of economic recession in which more firms face distress situations and have to convince stakeholders (possibly facing problems themselves) to support them. This is in line with previous studies providing evidence that CSP reduces firm risk in times of crises but that these effects diminish in importance afterwards (Bouslah et al., 2018; Broadstock et al., 2021). It follows that a high level of CSP may reduce $\mathrm{BL}$ in times of economic crisis, but not in times of economic upswing. Therefore, we propose the following hypothesis:

H1: In times of economic upswing, the level of a firm's CSP (overall as well as in each respective ESG pillar) does not affect its likelihood of bankruptcy. 
Table 1 Refinitiv ESG score categories, measures, and weights

\begin{tabular}{lllll}
\hline Environmental & & & \\
\hline Category & Resource use & Emissions & Innovation & \\
Number of measures & 20 & 22 & 19 & \\
Weights & $11 \%$ & $12 \%$ & $11 \%$ & \\
Social & & & & \\
Category & Workforce & Human rights & Community & Product responsibility \\
Number of measures & 29 & 8 & 14 & 12 \\
Weights & $16 \%$ & $4.5 \%$ & $8 \%$ & $7 \%$ \\
Governance & & & & \\
Category & Management & Shareholders & CSR strategy & \\
Number of measures & 34 & 12 & 8 & \\
Weights & $19 \%$ & $7 \%$ & $4.5 \%$ & \\
\hline
\end{tabular}

The table exhibits the three pillars of ESG, namely environment, social, and governance. Further, it shows the determined categories in each pillar, the number of measures in each category, and the overall weight in the Refinitiv ESG score. Source: Author's illustration based on Refinitiv (2021)
We further identify a reason justifying the examination of CSP percentage change as a variable of interest. As investing in CSP evokes costs (Cheng et al., 2014; Servaes \& Tamayo, 2013), it reduces firms' available funds and, therefore, initially increases the likelihood of bankruptcy. Only in the case of a subsequent positive effect on stakeholders, the net effect of a CSP increase may be positive (McWilliams \& Siegel, 2001). Hence, if such positive effects of CSP are only present in times of crisis, investments in ESG endeavors increase firms' BL in times of economic upswing. For this reason, we want to examine the effect of CSP change and propose the following hypothesis:

H2: In times of economic upswing, an increase in a firm's CSP level (overall as well as in each respective ESG pillar) increases its likelihood of bankruptcy.

\section{Data and Methodology}

\section{Sample Description}

This paper improves upon prior CSP-bankruptcy research, which has either a limited number of observations or solely categorical indicators for CSP, by using a robust sample and a continuous measure for CSP overall and in the respective ESG pillars. For the sample selection process, we started with data of the whole TR Eikon US universe, i.e., approx. 2.400 publicly-listed US-firms. Due to missing values, especially for the $Z$ and the ESG scores, the final sample includes a panel of 6696 firm-year observations (i.e., 1.215 firms) listed in the US from 2010 to 2019; the whole period is classified as a time of economic upswing (NBER, 2021). We collected firm-level data, such as total assets or total debts, from TR Eikon and dropped financial institutions due to their unique capital structure and different treatment of leverage (Brav, 2009; Kim et al., 2014). Further, we removed all observations with missing values and winsorized the variable $Z$ scores at the 1st and 99th percentiles. Moreover, to mitigate the influence of outliers and receive a more symmetric distribution in the data, specific variables such as total assets were transformed with the natural logarithm. In Appendix 1, Table 7 provides an overview of all applied variables.

\section{Measuring CSP}

We measured a firm's CSP with Refinitiv ESG scores retrieved from the TR Eikon database. Refinitiv ESG scores are widely used in literature (see amongst others: Dyck et al., 2019; Garcia et al., 2017; Ioannou \& Serafeim, 2012), are less prone to selection bias, and show more relevant results in terms of variability and distribution than comparable ESG ratings (Desender \& Epure, 2015; Dorfleitner et al., 2015; Ioannou \& Serafeim, 2011). Refinitiv ESG scores cover $80 \%$ of global market capitalization and use data from the public domain, e.g., annual reports, NGO websites, and news sources for evaluation. ESG specialists and algorithms analyze over 400 metrics throughout the evaluation process. Refinitiv assesses the environmental pillar performance by the categories: resource use, emissions, and innovation; the social pillar: workforce, human rights, community, and product responsibility; the governance pillar: management, shareholders, and CSR strategy. Each category contains several subcategories with industry-specific weights (for a detailed description, see Table 1 and Refinitiv, 2021). In this study, we used both the overall ESG score and the three ESG pillar scores. All scores range from 0 to 100, where 0 is the worst possible performance while 100 shows the best possible performance. In sum, we are confident that we received a high-quality CSP measure and high ESG 

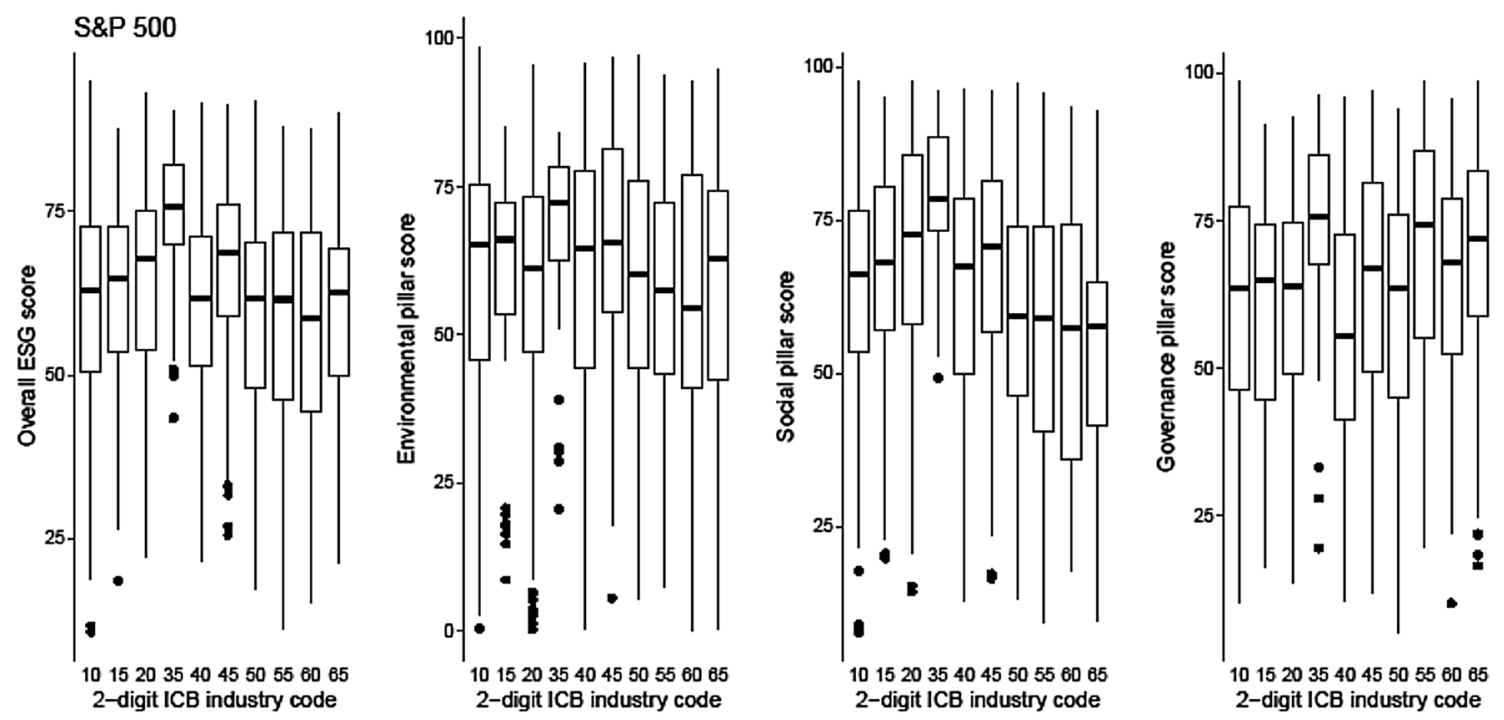

Fig. 1 Boxplot of ESG performance by industry. For ICB code description see Appendix 1 and www.ftse.com/products/downloads/ICB_Rules_ new.pdf

data density within the sample. Figure 1 provides a boxplot showing the average overall ESG and pillar performance by industry, respectively.

Moreover, based on our hypotheses, we were also interested in the annual percentage change in CSP, i.e., overall and in the respective pillar. We downloaded the data from the TR Eikon database and saved them in the respective delta variable, e.g., ESGDelta or EnvDelta.

\section{Measuring the Probability of Bankruptcy}

While Cooper and Uzun (2019) measured bankruptcy with the actual default of a firm, we followed Richardson et al. (2015) and Boubaker et al. (2020) by using the $Z$ score as a predictor of BL. Several reasons support this approach: (i) our objective is to investigate how CSP affects BL and not whether it leads to bankruptcy, since there might be firms using strategic bankruptcy at an early distress stage while others wait as long as possible (James, 2016); (ii) the measure is based on a profound theoretical framework (Altman, 1968); (iii) in general, $Z$ score models outperform hazard and market-based models (Boubaker et al., 2020); (iv) the results of a recent longitudinal study strongly support the usefulness of the $Z$ score (Altman et al., 2017). The $Z$ score uses a multivariate formula approach to predict the financial health of a firm. Five business ratios are calculated and weighted through the formula based on the Altman framework (for a more detailed and formalistic description, see Boubaker et al., 2020). The $Z$ score is a continuous measure and indicates a high bankruptcy probability for firms with a score below 1.88. Firms that show a value between 1.88 and
2.99 are questionable, while a value above 2.99 signifies a low default risk.

\section{Empirical Strategy}

The empirical strategy of this study includes fixed effects regressions as they show less restriction than random effects models. We performed within-group transformation to eliminate the time-invariant effects $\left(\alpha_{\mathrm{i}}\right)$ to conduct firm-level analyses cross-sectionally and over time. Nevertheless, we also performed the Hausman test to verify that a fixed effects model is more appropriate than a random effects model (Harrison \& Berman, 2016). Moreover, we argue that ESG scores do not show much variation for a specific firm over time, while the scores vary widely cross-sectional. Consequently, to avoid the risk of ruling out the effect of ESG pillar scores on firm-level, we used industry fixed effects rather than firm fixed effects (Arouri \& Pijourlet, 2017; Servaes \& Tamayo, 2013).

In terms of heteroskedasticity, we conducted the BreuschPagan test. Accordingly, robust and clustered standard errors were employed. To alleviate endogeneity concerns, i.e., reverse causality concerns, the explanatory variables and control variables in our models are lagged one period (Fernando et al., 2017; Flammer, 2015). The base model (1) can be illustrated as follows:

$$
\text { ZScore }_{i, t}=\beta_{0}+\beta_{1} \operatorname{CSP}_{i, t-1}+\beta_{2} \text { controls }_{i, t-1}+\eta_{j}+\theta_{t}+\varepsilon_{i, j, t}
$$


Table 2 Descriptive statistics

\begin{tabular}{lllllllll}
\hline & $\mathrm{N}$ & Mean & SD & Min & p25 & Median & p75 & Max \\
\hline ZScore & 6696 & 6.7709 & 8.2212 & -24.7041 & 2.4315 & 4.6444 & 8.0527 & 71.0269 \\
ESGScore & 6696 & 43.5267 & 20.1191 & 0.7999 & 27.1125 & 40.8701 & 59.3362 & 95.0733 \\
ESGDelta & 6694 & 9.6892 & 64.3975 & -98.6292 & -4.3220 & 2.7959 & 14.6634 & 2909.8002 \\
EnvPillar & 6696 & 32.0142 & 29.1218 & 0 & 2.1702 & 26.5150 & 57.5544 & 98.5481 \\
EnvDelta & 5176 & 39.3177 & 409.0271 & -100 & -3.7423 & 1.8783 & 14.1844 & $19,356.6680$ \\
SocPillar & 6696 & 45.8473 & 21.3415 & 0.8210 & 29.0851 & 42.9813 & 61.4571 & 97.7517 \\
SocDelta & 6694 & 10.4155 & 88.3525 & -98.3954 & -4.4444 & 1.1944 & 11.5659 & 4600.5330 \\
GovPillar & 6696 & 49.8680 & 23.0950 & 0.2516 & 30.9318 & 50.2577 & 68.6550 & 98.7234 \\
GovDelta & 6694 & 16.3470 & 122.9686 & -96.9819 & -11.0491 & 2.3920 & 23.1449 & 6217.5344 \\
Leverage & 6696 & 0.2911 & 0.2307 & 0 & 0.1464 & 0.2705 & 0.3921 & 3.8920 \\
Size & 6696 & 22.4351 & 1.5077 & 15.7646 & 21.4637 & 22.3811 & 23.4450 & 27.0362 \\
Profitability & 6696 & 6.0968 & 11.7510 & -139.6500 & 3.4500 & 6.4900 & 10.4000 & 169.9200 \\
Liquidity & 6696 & 0.3935 & 0.2219 & 0.0088 & 0.2091 & 0.3818 & 0.5479 & 0.9982 \\
\hline
\end{tabular}

The descriptive statistics for the variables used in the panel data models are reported. Additionally, we present the median since it is a more robust measure for central tendency than the mean. The standard deviation (SD) is presented to show the dispersion of a variable relative to its mean. Furthermore, the minimum (Min), the value for the 25th percentile (p25), the 75th percentile (p75), and the maximum (Max) are presented

ZScore $_{i, t}$ represents the dependent variable indicating the probability of bankruptcy within 2 years. To test our hypotheses, the coefficient of interest is $\beta_{1}$. Furthermore, established control variables for leverage, size, profitability, and liquidity were stored in the vector controls $_{i, t}$ (Cooper \& Uzun, 2019; for a detailed variable description see Table 7 in Appendix 1). In Eq. (1), $i$ denotes the firm dimension, $t$ is the time-series dimension, $\eta_{j}$ are two-digit ICB industry fixed effects, $\theta_{t}$ are year fixed effects, and $\varepsilon_{i, j, t}$ denotes the error term. However, we are aware that by doing so we cannot ensure causality in our findings. For this reason, we address the remaining endogeneity concerns in the "Robustness Tests" section by inter alia running instrumental variable regressions as conducted in Cheng et al. (2014) and Aouadi and Marsat (2018).

\section{Results}

\section{Descriptive Statistics and Correlations}

Table 2 summarizes the descriptive statistics, including the number of observations ( $\mathrm{N}$ ), means (Mean), standard deviations (SD), minimums (Min), 25th percentiles (p25), medians (Median), 75th percentiles (p75), and maximums (Max). The dependent variable ZScore shows a high SD compared to the mean. This might be the result of outliers at both ends of the data $(\operatorname{Min}=-24.7041$ and $\operatorname{Max}=71.0269)$. However, the 25th and 75th percentile are close to the median. Regarding ESG ratings, on average firms perform best in the governance pillar (Mean $=49.8680$ ), while the average performance is lowest in the environmental pillar (Mean =32.0142). In each pillar, the scores vary widely. For instance, in the environmental pillar, the lowest score is 0.00 , and the highest is 98.529. On average, firms improved their performance in the environmental pillar most (see Mean EnvDelta $=39.3177$ ) over the period 2010-2019. In sum, we did not observe issues that might lead to computational problems.

Furthermore, to detect potential computational problems due to multicollinearity, Pearson correlation coefficients were calculated. Table 3 presents the pairwise correlation matrix. No correlation exceeds the value 0.622 (between Size and EnvPillar; except for the correlations between the ESG measures), which benefited our further regression analyses. The correlations concerning Size imply that larger firms try to achieve higher ratings, particularly in the environmental pillar. These firms might do so as they receive greater attention and are able to allocate more resources to ESG endeavors. As can be seen, the ESG measures show a high correlation with each other. However, since we did not use them in the same model, no computational problems were expected. Apart from that, the variables for CSP level (e.g., EnvPillar) and CSP delta (e.g., EnvDelta) do not show critical correlations.

\section{Regression Results}

We examined the relationship between CSP and BL with model (1), as described in the "Empirical Strategy" section. Table 4 presents the results for our fixed effects regression using the $Z$ score as dependent variable. All control variables show an economic meaningful and significant effect on bankruptcy probability (at the 1 percent significance level). Regarding the overall ESG score models (see Columns 


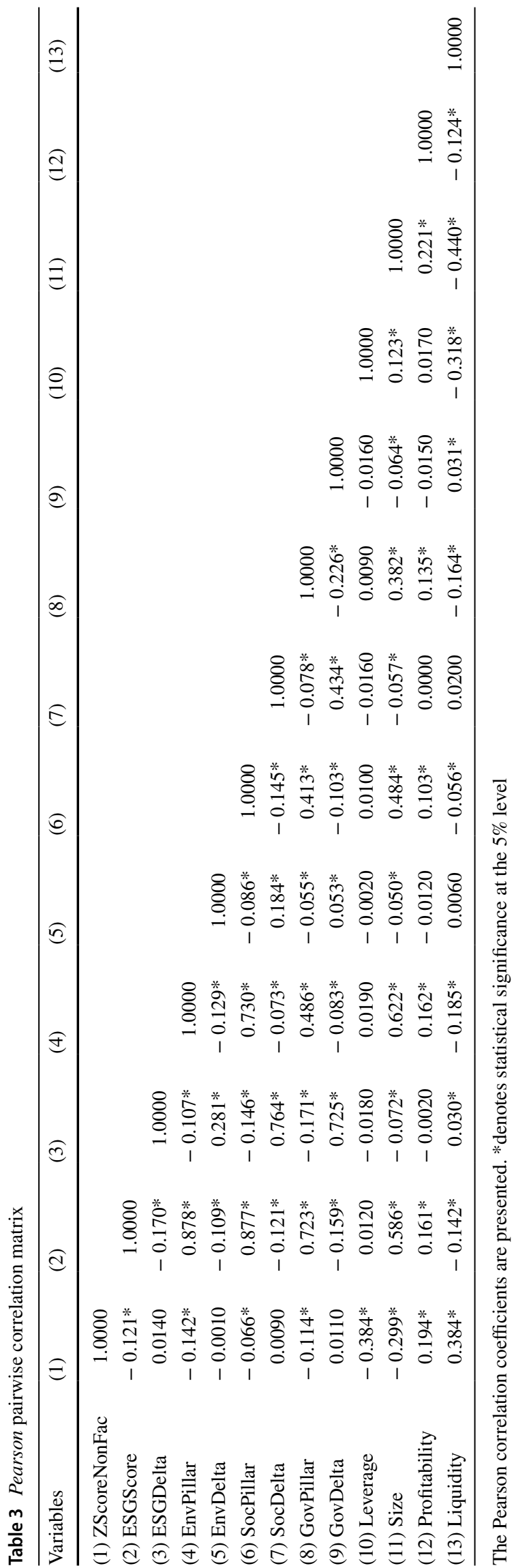

1 and 2), the results show that the 1-year lagged level of CSP (Column 1, ESGScore) does not affect the likelihood of bankruptcy. This is in line with $\mathbf{H 1}$ arguing that a high CSP level has no advantage when facing distress in times of upswing. Furthermore, increasing CSP in $t-1$ (Column 2, ESGDelta) lowers the $Z$ score in the following year (at the 5 percent significance level), i.e., increases BL for US-listed firms. This finding supports our hypothesis $\mathbf{H 2}$ considering the costs of ESG investments in a beneficial economic environment, where no positive effects of CSP appear.

For the environmental pillar (Columns 3 and 4), no significant negative effects can be observed. We argue that the increasing importance of environmental performance and the increased sensitivity to climate change in society (Dyck et al., 2019) might be the reason for that. Environmental engagement seems to almost pay off in times of upswing, e.g., because stakeholders such as customers accept price markups or reward environmentally sustainable firms through their purchasing behavior. Apart from that, a current study provides evidence that banks value the environmental performance of their borrowers (Chen et al., 2020).

In the social pillar (see Columns 5 and 6), the results are consistent with those of the overall ESG score models, while the governance pillar's results differ from the overall findings (see Column 7 and 8). Consequently, the social pillar seems to be the main driver for the effects in the overall models. We argue that higher costs through the increase in the categories workforce, human rights, community, and product responsibility (subcategories of the social pillar score) do not pay off immediately and, consequently, increase bankruptcy probability.

For the governance pillar, the level of CSP seems to be more important (GovPillar; see Column 7). We observe a negative and highly significant (at the 1 percent level) coefficient, while a change in governance performance (GovDelta; see Column 8) shows no significant effect. We argue that firms' average level of governance may be too high for times of economic upswing and leads to management distraction from their core business. It seems that in times of upswing, the costs of maintaining control and reporting structures, outweigh their advantages.

\section{Robustness Tests}

So far, the results from the previous section indicate that the level of CSP (in the governance pillar) and increasing CSP (overall and in the social pillar) raises the likelihood of bankruptcy during times of economic upswing. However, this relation contains endogenous potential. Such a potential can occur when unobservable and non-time-invariant factors affect both CSP and CFP, i.e., BL. For this reason, in the vein of Kim et al. (2014), we included additional control 
Table 4 CSP and the probability of bankruptcy in times of upswing

\begin{tabular}{|c|c|c|c|c|c|c|c|c|}
\hline & $\begin{array}{l}\text { (1) } \\
\text { ESG }\end{array}$ & $\begin{array}{l}\text { (2) } \\
\text { ESGDelta }\end{array}$ & $\begin{array}{l}\text { (3) } \\
\text { Env }\end{array}$ & $\begin{array}{l}\text { (4) } \\
\text { EnvDelta }\end{array}$ & $\begin{array}{l}\text { (5) } \\
\text { Soc }\end{array}$ & $\begin{array}{l}(6) \\
\text { SocDelta }\end{array}$ & $\begin{array}{l}\text { (7) } \\
\text { Gov }\end{array}$ & $\begin{array}{l}\text { (8) } \\
\text { GovDelta }\end{array}$ \\
\hline ESGScore & $\begin{array}{l}-0.0087 \\
(0.007)\end{array}$ & & & & & & & \\
\hline ESGDelta & & $\begin{array}{l}-0.0016^{* *} \\
(0.0007)\end{array}$ & & & & & & \\
\hline EnvPillar & & & $\begin{array}{l}0.0026 \\
(0.0066)\end{array}$ & & & & & \\
\hline EnvDelta & & & & $\begin{array}{l}-0.0001 \\
(0.0001)\end{array}$ & & & & \\
\hline SocPillar & & & & & $\begin{array}{l}0.0027 \\
(0.0086)\end{array}$ & & & \\
\hline SocDelta & & & & & & $\begin{array}{l}-0.0011^{* * *} \\
(0.0003)\end{array}$ & & \\
\hline GovPillar & & & & & & & $\begin{array}{l}-0.015^{* * *} \\
(0.0042)\end{array}$ & \\
\hline GovDelta & & & & & & & & $\begin{array}{l}-0.0006 \\
(0.0005)\end{array}$ \\
\hline Leverage & $\begin{array}{l}-10.5817^{* * *} \\
(3.1548)\end{array}$ & $\begin{array}{l}-10.5527 * * * \\
(3.1506)\end{array}$ & $\begin{array}{l}-10.5354 * * * \\
(3.1454)\end{array}$ & $\begin{array}{l}-10.1295^{* * *} \\
(2.922)\end{array}$ & $\begin{array}{l}-10.5396^{* * *} \\
(3.1528)\end{array}$ & $\begin{array}{l}-10.5528 * * * \\
(3.1489)\end{array}$ & $\begin{array}{l}-10.6201 * * * \\
(3.1197)\end{array}$ & $\begin{array}{l}-10.5507 * * * \\
(3.1519)\end{array}$ \\
\hline Size & $\begin{array}{l}-1.0633 * * * \\
(0.2765)\end{array}$ & $\begin{array}{l}-1.1462 * * * \\
(0.2491)\end{array}$ & $\begin{array}{l}-1.174 * * * \\
(0.2427)\end{array}$ & $\begin{array}{l}-0.8617 * * * \\
(0.1752)\end{array}$ & $\begin{array}{l}-1.164 * * * \\
(0.3091)\end{array}$ & $\begin{array}{l}-1.145^{* * *} \\
(0.2506)\end{array}$ & $\begin{array}{l}-1.0525^{* * * *} \\
(0.2407)\end{array}$ & $\begin{array}{l}-1.1438 * * * \\
(0.2496)\end{array}$ \\
\hline Rentability & $\begin{array}{l}0.2309 * * * \\
(0.057)\end{array}$ & $\begin{array}{l}0.2303 * * * \\
(0.0565)\end{array}$ & $\begin{array}{l}0.2301 * * * \\
(0.0562)\end{array}$ & $\begin{array}{l}0.486 * * * \\
(0.0713)\end{array}$ & $\begin{array}{l}0.2302 * * * \\
(0.0563)\end{array}$ & $\begin{array}{l}0.2303 * * * \\
(0.0565)\end{array}$ & $\begin{array}{l}0.2326 * * * \\
(0.057)\end{array}$ & $\begin{array}{l}0.2301 * * * \\
(0.0564)\end{array}$ \\
\hline Liquidity & $\begin{array}{l}8.0737 * * * \\
(2.0071)\end{array}$ & $\begin{array}{l}7.9606 * * * \\
(1.9917)\end{array}$ & $\begin{array}{l}7.9274 * * * \\
(2.0085)\end{array}$ & $\begin{array}{l}4.0632 * * * \\
(1.1225)\end{array}$ & $\begin{array}{l}7.9264 * * * \\
(1.9548)\end{array}$ & $\begin{array}{l}7.959 * * * \\
(1.9925)\end{array}$ & $\begin{array}{l}8.0526 * * * \\
(1.9779)\end{array}$ & $\begin{array}{l}7.9624 * * * \\
(1.9902)\end{array}$ \\
\hline Observations & 6696 & 6694 & 6696 & 5167 & 6696 & 6694 & 6696 & 6694 \\
\hline R-squared & 0.2934 & 0.2932 & 0.2931 & 0.3964 & 0.2931 & 0.2932 & 0.2946 & 0.2931 \\
\hline $\operatorname{Adj} R^{2}$ & 0.2919 & 0.2917 & 0.2916 & 0.3948 & 0.2916 & 0.2917 & 0.2931 & 0.2916 \\
\hline Industry FE & Yes & Yes & Yes & Yes & Yes & Yes & Yes & Yes \\
\hline Time FE & Yes & Yes & Yes & Yes & Yes & Yes & Yes & Yes \\
\hline
\end{tabular}

The table presents industry fixed effects regression of Altman $Z$ score on the respective explanatory variable as defined in hypothesis $\mathrm{H} 1$ for the period 2010 to 2019 . In parenthesis, the clustered and heteroskedasticity-robust standard errors are shown. The ***, **, and * denote statistical significance at the 1,5 , and $10 \%$ levels, respectively

variables which influence both CSP and CFP in model (1): selling, general, and administrative expenses and research and development expenses (we also included dummy variables that indicate whether the respective values are missing or not). The results (not reported) support our findings.

Furthermore, based on the approach of Aouadi and Marsat (2018), we controlled the sensitivity of our results by observing sample splits (see Table 5). By doing so, we created the following additional insights. First, the level of social performance is insignificant for both FDR $(Z$ score $<1.88)$ and non-FDR ( $Z$ score $>2.99$ ) firms (see Columns 1 and 3 ). Second, the split between FDR and non-FDR firms shows that the negative effect of SocDelta is mainly driven by non-FDR firms investing in social issues (see Column 4). In contrast to that, the coefficient for FDR firms indicates a positive relation (see Column 2). In the next step, we used the median of the variable Size (22.3811) to split the sample in smaller and bigger firms. As can be seen in Columns 5 and 6, the coefficient of SocDelta is solely significant for smaller firms. We argue that resources are scarcer in smaller firms and therefore additional costs for CSP - which are not being compensated by additional benefits in times of upturn - increase bankruptcy probability. Overall, the results support our previous findings.

Nevertheless, in terms of causation, the interpretation of our results ought to be done with care since the previous approaches cannot rule out endogeneity concerns completely. That being so, we additionally applied an instrumental variable approach to mitigate those remaining concerns. To test the robustness of our overall results, we aimed to find an exogenous link in the CSP-bankruptcy relationship. By 
Table 5 Sample splits and 2SLS regression-CSP and the probability of bankruptcy

\begin{tabular}{|c|c|c|c|c|c|c|c|c|}
\hline & & (2) & (3) & (4) & (5) & (6) & (7) & (8) \\
\hline & \multicolumn{2}{|l|}{ FDR firms } & \multicolumn{2}{|l|}{ Non-FDR firms } & \multicolumn{2}{|c|}{$\begin{array}{l}\text { Bigger firms Smaller } \\
\text { firms }\end{array}$} & \multicolumn{2}{|l|}{ ESG } \\
\hline & Soc & SocDelta & Soc & SocDelta & SocDelta & SocDelta & First_stage & Second_stage \\
\hline SocPillar & $\begin{array}{l}-0.0083 \\
(0.006)\end{array}$ & & $\begin{array}{l}0.0002 \\
(0.0085)\end{array}$ & & & & & \\
\hline SocDelta & & $\begin{array}{l}0.0027 * \\
(0.0013)\end{array}$ & & $\begin{array}{l}-0.0018^{* *} \\
(0.0006)\end{array}$ & $\begin{array}{l}-0.001 \\
(0.0016)\end{array}$ & $\begin{array}{l}-0.0014 * * * \\
(0.0003)\end{array}$ & & \\
\hline indMeanESGYear & & & & & & & $\begin{array}{l}0.199 \\
(0.226)\end{array}$ & \\
\hline Pred. ESGScore & & & & & & & & $\begin{array}{l}-0.555^{*} \\
(0.317)\end{array}$ \\
\hline ESGDelta & & & & & & & $\begin{array}{l}-0.039 * * \\
(0.013)\end{array}$ & $\begin{array}{l}-0.024^{*} \\
(0.013)\end{array}$ \\
\hline Leverage & $\begin{array}{l}-1.7925^{* *} \\
(0.7714)\end{array}$ & $\begin{array}{l}-1.7976 * * \\
(0.7522)\end{array}$ & $\begin{array}{l}-11.6886^{* * * *} \\
(3.5823)\end{array}$ & $\begin{array}{l}-11.7013 * * * \\
(3.5847)\end{array}$ & $\begin{array}{l}-6.173 * * * \\
(1.6103)\end{array}$ & $\begin{array}{l}-11.4806^{* * *} \\
(3.792)\end{array}$ & $\begin{array}{l}-4.12 * * \\
(1.667)\end{array}$ & $\begin{array}{l}-12.804 * * * \\
(1.425)\end{array}$ \\
\hline Size & $\begin{array}{l}0.2523 * * \\
(0.0989)\end{array}$ & $\begin{array}{l}0.1864 * * \\
(0.0684)\end{array}$ & $\begin{array}{l}-1.3194 * * * \\
(0.3791)\end{array}$ & $\begin{array}{l}-1.3251 * * * \\
(0.3274)\end{array}$ & $\begin{array}{l}-0.1867 \\
(0.2139)\end{array}$ & $\begin{array}{l}-2.6979 * * * \\
(0.2887)\end{array}$ & $\begin{array}{l}8.687 * * * \\
(0.41)\end{array}$ & $\begin{array}{l}3.684 \\
(2.76)\end{array}$ \\
\hline Profitability & $\begin{array}{l}0.0545^{* *} \\
(0.0209)\end{array}$ & $\begin{array}{l}0.055^{* *} \\
(0.0212)\end{array}$ & $\begin{array}{l}0.1519 \\
(0.0907)\end{array}$ & $\begin{array}{l}0.1521 \\
(0.091)\end{array}$ & $\begin{array}{l}0.3991 * * * \\
(0.1207)\end{array}$ & $\begin{array}{l}0.2551 * * * \\
(0.0452)\end{array}$ & $\begin{array}{l}0.077 \\
(0.07)\end{array}$ & $\begin{array}{l}0.275 * * * \\
(0.028)\end{array}$ \\
\hline Liquidity & $\begin{array}{l}-2.9355 \\
(1.9242)\end{array}$ & $\begin{array}{l}-3.1119 \\
(1.8909)\end{array}$ & $\begin{array}{l}9.3283 * * * \\
(2.7421)\end{array}$ & $\begin{array}{l}9.3291 * * * \\
(2.7725)\end{array}$ & $\begin{array}{l}3.3168 * * \\
(1.0578)\end{array}$ & $\begin{array}{l}8.9988 * * * \\
(2.3528)\end{array}$ & $\begin{array}{l}12.052 * * * \\
(2.689)\end{array}$ & $\begin{array}{l}14.62 * * * \\
(3.878)\end{array}$ \\
\hline Observations & 1285 & 1285 & 4585 & 4583 & 3343 & 3351 & 6694 & 6694 \\
\hline $\operatorname{Adj} R^{2}$ & 0.1279 & 0.2378 & 0.2514 & 0.2518 & 0.3753 & 0.287 & 0.382 & \\
\hline Industry FE & Yes & Yes & Yes & Yes & Yes & Yes & Yes & Yes \\
\hline Time FE & Yes & Yes & Yes & Yes & Yes & Yes & Yes & Yes \\
\hline $\begin{array}{l}\text { Weak instruments } \\
\text { test }\end{array}$ & & & & & & & & $45.4780(p=0.0000)$ \\
\hline Wu-Hausman test & & & & & & & & $7.65856(p=0.0057)$ \\
\hline Wald test & & & & & & & & $1519.31(p=0.0000)$ \\
\hline
\end{tabular}

The table presents results of two-stage least squares (2SLS) with instrumental variable (IV) regressions for the period 2010 to 2019 . In parenthesis, robust standard errors are shown. The ***, **, and * denote statistical significance at the 1,5 , and $10 \%$ levels, respectively. Furthermore, the table provides the specification tests: test for weak instruments, Wu-Hausman test, test of overidentifying restrictions, and Wald statistic for the robust test on the 2 SLS coefficient on the $Z$ score

following prior studies (Aouadi \& Marsat, 2018; Cheng et al., 2014; El Ghoul et al., 2017), the mean year-industry CSP served as an instrument for CSP. While excluding the focal firm, the first-stage regression predicts the value of the overall ESG score. Those fitted values, i.e., $\hat{y}$, from the first-stage regression replace the original CSP scores (ESGScore) in the second-stage regression. Accordingly, since this approach has often been used in prior studies, we are confident that this is a suitable exogenous proxy for CSP. Table 5 presents the results of the two-stage least squares (2SLS) regression in Columns 7 and 8 . As can be seen, the results strongly support our previous findings since they indicate that increasing CSP (i.e., ESGDelta) in $t$ - 1 causes higher BL in $t$.

Based on the previously mentioned studies, we built our hypotheses on the assumption that in times of crisis CSP affects BL positively, i.e., CSP lowers BL. To test whether there is an identical effect in our sample, we run the same regressions as in base model (1) on a sample containing the period of the financial crisis from 2007 to 2009. As can be seen in Table 6, the level of CSP becomes more important in times of crisis (the results are qualitatively the same for the period 2006 to 2009 ; not reported). More precisely, a higher overall CSP significantly (at the five percent level) increases the Z-Score, i.e., lowers BL (see Column 1). Apart from that, the identical effect appears in the environmental (see Column 3) and social pillar (see Column 5). We attribute these positive effects to improved relationships, e.g., with customers, employees, and suppliers, which is in line with stakeholder theory. As in the results regarding 2010 to 2019, the governance pillar affects BL differently. No significant positive effect can be observed for the governance 
Table 6 CSP and the probability of bankruptcy in times of downturn

\begin{tabular}{|c|c|c|c|c|c|c|c|c|}
\hline & $\begin{array}{l}\text { (1) } \\
\text { ESG }\end{array}$ & $\begin{array}{l}(2) \\
\text { ESGDelta }\end{array}$ & $\begin{array}{l}\text { (3) } \\
\text { Env }\end{array}$ & $\begin{array}{l}\text { (4) } \\
\text { EnvDelta }\end{array}$ & $\begin{array}{l}(5) \\
\text { Soc }\end{array}$ & $\begin{array}{l}(6) \\
\text { SocDelta }\end{array}$ & $\begin{array}{l}(7) \\
\text { Gov }\end{array}$ & $\begin{array}{l}\text { (8) } \\
\text { GovDelta }\end{array}$ \\
\hline ESGScore & $\begin{array}{l}0.0229 * * \\
(0.0087)\end{array}$ & & & & & & & \\
\hline ESGDelta & & $\begin{array}{l}-0.0011 \\
(0.0013)\end{array}$ & & & & & & \\
\hline EnvPillar & & & $\begin{array}{l}0.0159 * * \\
(0.0068)\end{array}$ & & & & & \\
\hline EnvDelta & & & & $\begin{array}{l}0.0004 \\
(0.0005)\end{array}$ & & & & \\
\hline SocPillar & & & & & $\begin{array}{l}0.0223 * * * \\
(0.0064)\end{array}$ & & & \\
\hline SocDelta & & & & & & $\begin{array}{l}0.0004 \\
(0.0012)\end{array}$ & & \\
\hline GovPillar & & & & & & & $\begin{array}{l}0.0056 \\
(0.007)\end{array}$ & \\
\hline GovDelta & & & & & & & & $\begin{array}{l}-0.0031 * * \\
(0.0013)\end{array}$ \\
\hline Leverage & $\begin{array}{l}-6.4144 * * * \\
(1.2389)\end{array}$ & $\begin{array}{l}-6.6547 * * * \\
(1.265)\end{array}$ & $\begin{array}{l}-6.5495^{* * *} \\
(1.2144)\end{array}$ & $\begin{array}{l}-6.617 * * * \\
(1.2615)\end{array}$ & $\begin{array}{l}-6.4678 * * * \\
(1.2574)\end{array}$ & $\begin{array}{l}-6.6441 * * * \\
(1.2585)\end{array}$ & $\begin{array}{l}-6.5844 * * * \\
(1.2252)\end{array}$ & $\begin{array}{l}-6.7338^{* * *} \\
(1.2827)\end{array}$ \\
\hline Size & $\begin{array}{l}-1.0504 * * * \\
(0.2327)\end{array}$ & $\begin{array}{l}-0.8333 * * * \\
(0.2385)\end{array}$ & $\begin{array}{l}-1.0469 * * * \\
(0.223)\end{array}$ & $\begin{array}{l}-0.8394 * * * \\
(0.233)\end{array}$ & $\begin{array}{l}-1.0534 * * * \\
(0.2251)\end{array}$ & $\begin{array}{l}-0.8351 * * * \\
(0.2363)\end{array}$ & $\begin{array}{l}-0.8671 * * * \\
(0.2389)\end{array}$ & $\begin{array}{l}-0.8218^{* * *} \\
(0.24)\end{array}$ \\
\hline Rentability & $\begin{array}{l}0.3632 * * * \\
(0.0837)\end{array}$ & $\begin{array}{l}0.3706 * * * \\
(0.0887)\end{array}$ & $\begin{array}{l}0.3652 * * * \\
(0.0841)\end{array}$ & $\begin{array}{l}0.3704 * * * \\
(0.0885)\end{array}$ & $\begin{array}{l}0.3606 * * * \\
(0.0819)\end{array}$ & $\begin{array}{l}0.3708 * * * \\
(0.0885)\end{array}$ & $\begin{array}{l}0.3695 * * * \\
(0.0882)\end{array}$ & $\begin{array}{l}0.3683 * * * \\
(0.0896)\end{array}$ \\
\hline Liquidity & $\begin{array}{l}6.7097 * * * \\
(1.7696)\end{array}$ & $\begin{array}{l}6.7924 * * * \\
(1.8004)\end{array}$ & $\begin{array}{l}6.7816^{* * * *} \\
(1.7607)\end{array}$ & $\begin{array}{l}6.8111^{* * *} \\
(1.7898)\end{array}$ & $\begin{array}{l}6.6457 * * * \\
(1.7478)\end{array}$ & $\begin{array}{l}6.8105^{* * *} \\
(1.7958)\end{array}$ & $\begin{array}{l}6.8004 * * * \\
(1.7919)\end{array}$ & $\begin{array}{l}6.8135 * * * \\
(1.7955)\end{array}$ \\
\hline Observations & 891 & 891 & 891 & 891 & 891 & 891 & 891 & 891 \\
\hline $\operatorname{Adj} R^{2}$ & 0.4379 & 0.4337 & 0.4378 & 0.4343 & 0.4392 & 0.4336 & 0.434 & 0.4355 \\
\hline Industry FE & Yes & Yes & Yes & Yes & Yes & Yes & Yes & Yes \\
\hline Time FE & Yes & Yes & Yes & Yes & Yes & Yes & Yes & Yes \\
\hline
\end{tabular}

The table presents industry fixed effects regression of Altman $Z$ score on the respective explanatory variable as defined in model (1) for the period 2007 to 2009 . In parenthesis, the clustered and heteroskedasticity-robust standard errors are shown. The $* * *, * *$, and $*$ denote statistical significance at the 1,5 , and $10 \%$ levels, respectively

level (see Column 7), while increasing governance performance in times of crisis increases BL (see Column 8). We argue that investing in governance performance in times of crisis comes too late or stakeholders perceive environmental and social issues as more important.

\section{Discussion}

While previous research observed the relationship between CSP and bankruptcy, using samples containing times of recessions, we examined the relationship for a time of economic upswing, i.e., between 2010 and 2019 (NBER, 2021). In contrast to the existing studies, our results show that the CSP level (except for the governance pillar) does not affect BL and more interestingly, that investing in CSP increases it. This is in line with our hypotheses, arguing that high CSP leads to loyal stakeholders but that in times of expansion, there is no need to have those, as the general environment is sufficient to resolve distress (H1). For this reason, increasing CSP in times of upswing mainly causes costs, which raise $\mathrm{BL}(\mathrm{H} 2)$.

The results concerning economic upswing might also be interpreted from the agency theory perspective introduced in the "Related Literature" section: Investing in CSP increases BL as it only causes additional costs that decrease profitability and, thus, firm health. However, the existing research and our results from times of downturn (see "Robustness Tests" section) indicate that there are positive effects of CSP. For this reason, we discard agency theory to 
explain the CSP-BL relationship when considering whole business cycles. Nevertheless, agency theory may be a helpful perspective when, e.g., investigating the efficiency of CSP investment strategies, particularly in times of upswing. An interesting research question might be whether agents (i.e., managers) focus on the same CSP investments that principles (i.e., shareholders/owners) would.

An alternative approach to interpret our results may be the dynamic character of CSP. Institutionalization theory delivers an explanation for the diminishing positive effects of CSP through diffusion, adoption, and increased isomorphism (Brower \& Dacin, 2020). The authors show for the relation between CSP and positive CFP that early compared to late adopters exhibited higher positive effects on profitability and firm value between 1991 and 2008. However, the positive effect of CSP on both measures became an increasingly weaker factor over time. This might lead to the assumption that our results show no positive effect on BL because CSP is already institutionalized as of 2010 and additional CSP investments did not pay off subsequently. As a result, high CSP firms should show a constant level while the other firms conduct catch-up investments to meet market expectations (Brower \& Dacin, 2020). We refrain from this approach as not only the ESGScore mean (2010: 59.92, 2019: 62.47) but also the mean of the top 5.0\% firms (2010: 81.12, 2019: 82.64) increased during the observation period. This suggests that CSP investments in the observed period were not mainly conducted to catch up but to further increase the CSP level.

Another approach to explain our results might be that low CSP firms invest in CSP merely to harvest short-term benefits but that stakeholders can see through this deception, which leads to negative effects on BL. Current studies indicate that internal as well as external stakeholders can cause such negative effects. For instance, a recent study shows that hypocritical behavior increases the emotional exhaustion of employees and their intention to quit (Scheidler et al., 2019). By providing several examples regarding the effect on external stakeholders (e.g., incidents at McDonald's and Verizon), Carlos and Lewis (2018, p. 134) argue that: "[...] inconsistencies between claims and actions can stoke external stakeholders' perceptions of hypocrisy" and entail negative consequences. However, this approach cannot explain why the negative effects of CSP on BL only exist in times of upswing. For this reason, we suggest our initial hypothesis based on stakeholder theory to explain our findings.

Our findings show that a high CSP level has no positive effect and additional CSP investments increase BL in times of upswing. However, the studies of Lin and Dong (2018), Cooper and Uzun (2019), as well as Boubaker et al. (2020), and our robustness test show that high CSP reduces BL in times of crises. Thus, investing in CSP is costly in the short term but mitigates financial default risk in subsequent crises.

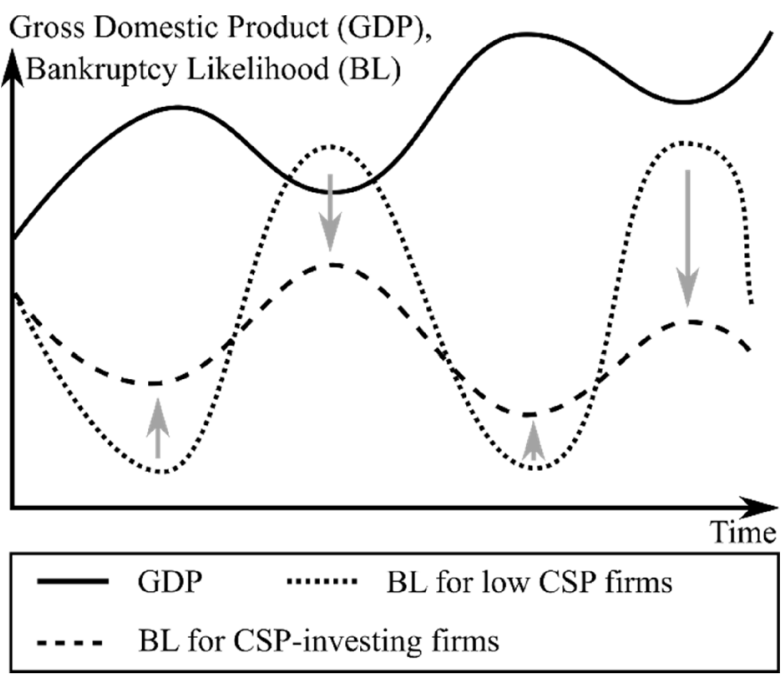

Fig. 2 Stylized effects of CSP on bankruptcy likelihood (BL)

Consequently, investing in CSP seems to be an instrument to smooth and balance the likelihood of bankruptcy over economic cycles (see Fig. 2). This connects to prior literature providing evidence that in times of crisis, CSP mitigates BL while this effect diminishes in importance after the crisis (e.g., Bouslah et al., 2018; Broadstock et al., 2021). In this vein, Ducassy (2013) shows that the positive connection between CSP and CFP exists, but after the turmoil, the significant link between both variables disappears. In sum, our findings confirm the stakeholder-based insurance-like effect of CSP on BL that Bouslah et al. (2018) pronounce for the CSP-firm risk relationship.

Besides the overall effects (which are mainly driven by the social pillar), our results provide insights regarding CSP on a more granular basis. First, a high level of governance increases BL in times of upswing. We explain this with the additional effort and distractions from the core business that governance tasks cause for the management. This is in line with existing literature distinguishing the governance pillar from the other pillars (Fabrizi et al., 2014; Kim et al., 2012; Lin \& Dong, 2018). Second, investing in the environmental pillar tends to almost pay off even in times of upswing as stakeholders seem to remunerate those investments. Third, investing in the social pillar could be a suitable turnaround measure as it indicates a decreasing BL for FDR firms. Improved internal (e.g., employee motivation) and external stakeholder relations (e.g., firm reputation) seem to be the underlying mechanisms. Finally, bigger firms face advantages compared to smaller firms when investing in CSP as they can bear the negative effects more easily.

Based on the results of this study, we derive the following implications for policymakers, practitioners, and scholars. For the latter, we open up space for future research. Scholars may incorporate the understanding that CSP exhibits a 
different impact on financial performance when considered in different economic contexts. While we use stakeholder theory to explain these effects, future research might also focus on institutionalization theory. They might also apply theories that include information asymmetry to explain why governance seems to play a distinct role in this context. According to our findings, CSP is a measure to mitigate the effects of economic crises rather than to increase firm performance. Therefore, scholars should focus on examining the CSP-bankruptcy relationship more extensively instead of merely investigating the CSP-CFP relationship (i.e., increased accounting or market-based performance). Furthermore, future research could address the longitudinal effect of ESG investments within a whole business cycle with more advanced methods.

Practitioners should be aware that a high level of CSP may not help in times of economic upswing, but it may improve firms' chances to survive distress in subsequent external crises. Moreover, when investing in CSP in "good" times, firms may focus on the environmental pillar if they want to minimize the short-term negative effects. In the case of necessary CSP divestment, we argue that firms (already having a high CSP level) should reduce their governance level as this pillar shows negative effects on BL. Furthermore, if a firm faces financial distress in times of upswing, social investments might help to resolve it. In general, policymakers should incentivize firms to invest in CSP in solid economic times as a preventive measure although the immediate effects on CFP are negative (see Fig. 2). As these effects hit small firms harder than bigger ones, policymakers might support small and medium enterprises in improving their CSP.

\section{Conclusion}

In this article, we investigate whether and how CSP, overall and in each ESG pillar, affects the likelihood of bankruptcy (i.e., financial failure) in times of economic upswing. Our empirical strategy involves applying fixed effects regressions on a sample of 6696 firm-year observations of U.S.-listed companies to test our hypotheses cross-sectionally and over time. By employing fixed effects, unobservable and timeinvariant factors that influence the $Z$ score have been eliminated and did not bias our results. To further address endogeneity concerns, we conducted an instrumental variable approach. In contrast to prior studies (Boubaker et al., 2020; Cooper \& Uzun, 2019; Lin \& Dong, 2018), we provide evidence that during times of economic prosperity, increasing CSP lowers the $Z$ score in the following year, i.e., expands BL. Furthermore, when focusing on the individual ESG pillars, we show that the social pillar is the main driver for this effect, while a high level of governance increases BL and investments in the environmental pillar seem to have no effect on BL.

Consequently, we make several contributions to the existing literature (Boubaker et al., 2020; Cheng et al., 2014; Cooper \& Uzun, 2019; Lee \& Faff, 2009): (i) To the best of our knowledge, this study is the first that examined the CSP-CFP relationship in times of economic upswing by using bankruptcy as an indicator for financial failure. (ii) In contrast to previous studies (Boubaker et al., 2020; Cooper \& Uzun, 2019), our results indicate that increasing CSP increases BL in times of upswing. However, we are able to fit our results into the existing literature and a consistent theoretical framework considering changing economic conditions. (iii) We used a representative and robust sample of 6696 firm-a observations and applied Refinitiv ESG scores as a continuous CSP measure. Furthermore, we differentiated between the three ESG pillars and offer an explanation for each pillar's results. (iv) We open up space for further research in the CSP-bankruptcy literature. That is because we provide novel insights that stakeholder theory may be a valid theoretical frame for CSP even if no effects are visible immediately. In addition, we point to institutionalization theory as an alternative approach to be investigated in future research. Moreover, we pronounce the different effects of each ESG pillar for further examination. Besides, firm size and FDR also play a role when investigating effects of CSP on financial failure.

Nevertheless, in this study, we recognize a number of limitations. First, instead of using actual financial failure, i.e., filing for Chapter 11, we employed the formalistic $Z$ score, a multivariate proxy that predicts the likelihood of bankruptcy within 2 years. However, since prior studies also applied the $Z$ score to collect more robust samples (e.g., Boubaker et al., 2020), we are confident that the $Z$ score is a reliable and accurate measure of financial distress. Additionally, in a recent study, the $Z$ score is still shown to be the most appropriate estimator for BL (Altman et al., 2017). Second, in this paper, the focus lies on large USlisted firms. Consequently, the results provided might not be generalizable to smaller or privately held firms. Moreover, implications based on our results for firms operating in different geographic regions, e.g., Europe or regions with different levels of economic development, i.e., emerging markets, have to be derived with care. Finally, we measured the multidimensional concept of CSP with Refinitiv ESG scores. Even though the rating process involves algorithmic and human evaluation over three pillars and 400 ESG metrics, doubts cannot be fully dispelled that these scores can precisely reflect the CSP of firms. However, since such an approach is common and widely used in research (e.g., Dyck et al., 2019; Liang \& Renneboog, 2017), we are confident that our results are robust. Overall, the limitations of the 
present study may encourage researchers to test and expand Appendix 1

our findings in other contexts and with other data.

See Table 7.

Table 7 Variable description

Independent variables

Altman $Z$ score (ZScore)

Explanatory variable

ESG combined score (ESGScore)

Environmental Pillar Score (EnvPillar)

Social Pillar Score (SocPillar)

Governance Pillar Score (GovPillar)

\section{ESGDelta}

EnvDelta

SocDelta

GovDelta

Control variables

\section{Leverage}

Size

Profitability

Liquidity

2-digit ICB Industry Codes

10

15

20

35

40

45

50

55

60

65
$Z$ score is calculated using data in its model for the fiscal period. The $Z$ score is a multivariate formula that measures the financial health of a company and predicts the probability of bankruptcy within 2 years. The $Z$ score combines five common business ratios using a weighting system calculated by Altman to determine the likelihood of bankruptcy. Typically, a score below 1.88 indicates that a company is likely heading for or is under the weight of bankruptcy. Conversely, companies that score above 2.99 are less likely to experience bankruptcy. Score between 2.99 and 1.88 is questionable

Refinitiv ESG combined score is an overall company score based on the reported information in the environmental, social and corporate governance pillars (ESG score) with an ESG controversies overlay

The environmental pillar measures a company's impact on living and non-living natural systems, including the air, land and water, as well as complete ecosystems. It reflects how well a company uses best management practices to avoid environmental risks and capitalize on environmental opportunities in order to generate long-term shareholder value

The social pillar measures a company's capacity to generate trust and loyalty with its workforce, customers and society, through its use of best management practices. It reflects the company's reputation and the health of its license to operate, which are key factors in determining its ability to generate long-term shareholder value

The corporate governance pillar measures a company's systems and processes, which ensure that its board members and executives act in the best interests of its long-term shareholders. It reflects a company's capacity, through its use of best management practices, to direct and control its rights and responsibilities through the creation of incentives, as well as checks and balances in order to generate long-term shareholder value

Annual percentage change in the ESG score, i.e. (ESG score $/$ ESG score $_{t-1}$ ) - 1

Annual percentage change in the environmental pillar score, i.e. (environmental pillar score//environmental pillar score $\left._{\mathrm{t}-1}\right)-1$

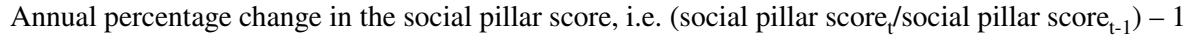

Annual percentage change in the governance pillar score, i.e. (governance pillar score $\mathrm{t}_{\mathrm{l}}$ governance pillar score $\left._{\mathrm{t}-1}\right)-1$

Total debt divided by total assets

Natural logarithm of total assets

This value is calculated as the income after taxes for the fiscal period divided by the average total assets and is expressed as percentage

Cash and short-term assets scaled by total assets

Technology

Telecommunications

Health Care

Real Estate

Consumer Discretionary

Consumer Staples

Industrials

Basic Materials

Energy

Utilities 
Funding Open Access funding enabled and organized by Projekt DEAL. No additional funding was received for conducting this study.

Data Availability Can be requested from the author.

\section{Declarations}

Conflict of interest There is no recent, present, or anticipated employment by any organization that may gain or lose financially through publication of this manuscript. The authors have no relevant financial or non-financial interests to disclose.

Code Availability R and Stata. Can be requested from the author.

Open Access This article is licensed under a Creative Commons Attribution 4.0 International License, which permits use, sharing, adaptation, distribution and reproduction in any medium or format, as long as you give appropriate credit to the original author(s) and the source, provide a link to the Creative Commons licence, and indicate if changes were made. The images or other third party material in this article are included in the article's Creative Commons licence, unless indicated otherwise in a credit line to the material. If material is not included in the article's Creative Commons licence and your intended use is not permitted by statutory regulation or exceeds the permitted use, you will need to obtain permission directly from the copyright holder. To view a copy of this licence, visit http://creativecommons.org/licenses/by/4.0/.

\section{References}

Altman, E. I. (1968). Financial ratios, discriminant analysis and the prediction of corporate bankruptcy. The Journal of Finance, 23, 589-609. https://doi.org/10.1111/j.1540-6261.1968.tb00843.x

Altman, E. I., Iwanicz-Drozdowska, M., Laitinen, E. K., \& Suvas, A. (2017). Financial distress prediction in an international context: A review and empirical analysis of Altman's Z-Score model. Journal of International Financial Management \& Accounting, 28, 131-171. https://doi.org/10.1111/jifm. 12053

Aouadi, A., \& Marsat, S. (2018). Do ESG controversies matter for firm value? Evidence from international data. Journal of Business Ethics, 151, 1027-1047. https://doi.org/10.1007/s10551-016-3213-8

Arouri, M., \& Pijourlet, G. (2017). CSR performance and the value of cash holdings: International evidence. Journal of Business Ethics, 140, 263-284. https://doi.org/10.1007/s10551-015-2658-5

Baird, D. G. (1987). A world without bankruptcy. Law and Contemporary Problems, 50, 173. https://doi.org/10.2307/1191499

Baldini, M., Maso, L. D., Liberatore, G., Mazzi, F., \& Terzani, S. (2018). Role of country- and firm-level determinants in environmental, social, and governance disclosure. Journal of Business Ethics, 150, 79-98. https://doi.org/10.1007/s10551-016-3139-1

Blacconiere, W. G., \& Patten, D. M. (1994). Environmental disclosures, regulatory costs, and changes in firm value. Journal of Accounting and Economics, 18, 357-377. https://doi.org/10.1016/ 0165-4101(94)90026-4

Bogan, V. L., \& Sandler, C. M. (2012). Are firms on the right page with Chapter 11? An analysis of firm choices that contribute to postbankruptcy survival. Applied Economics Letters, 19, 609-613. https://doi.org/10.1080/13504851.2011.591721

Boubaker, S., Cellier, A., Manita, R., \& Saeed, A. (2020). Does corporate social responsibility reduce financial distress risk? Economic Modelling, 91, 835-851. https://doi.org/10.1016/j.econmod.2020. 05.012
Bouslah, K., Kryzanowski, L., \& M'Zali, B. (2018). Social performance and firm risk: Impact of the financial crisis. Journal of Business Ethics, 149, 643-669. https://doi.org/10.1007/ s10551-016-3017-x

Brav, O. (2009). Access to capital, capital structure, and the funding of the firm. The Journal of Finance, 64, 263-308. https://doi.org/ 10.1111/j.1540-6261.2008.01434.x

Broadstock, D. C., Chan, K., Cheng, L. T. W., \& Wang, X. (2021). The role of ESG performance during times of financial crisis: Evidence from COVID-19 in China. Finance Research Letters, 38, 101716. https://doi.org/10.1016/j.frl.2020.101716

Brower, J., \& Dacin, P. A. (2020). An institutional theory approach to the evolution of the corporate social performance: Corporate financial performance relationship. Journal of Management Studies, 57, 805-836. https://doi.org/10.1111/joms. 12550

Carlos, W. C., \& Lewis, B. W. (2018). Strategic silence: Withholding certification status as a hypocrisy avoidance tactic. Administrative Science Quarterly, 63, 130-169. https://doi.org/10.1177/00018 39217695089

Chen, I.-J., Hasan, I., Lin, C.-Y., \& Nguyen, T. N. V. (2020). Do banks value borrowers' environmental record? Evidence from financial contracts. Journal of Business Ethics. https://doi.org/10.1007/ s10551-020-04621-2

Cheng, B., Ioannou, I., \& Serafeim, G. (2014). Corporate social responsibility and access to finance. Strategic Management Journal, 35, 1-23. https://doi.org/10.1002/smj.2131

Cooper, E., \& Uzun, H. (2019). Corporate social responsibility and bankruptcy. Studies in Economics and Finance, 36, 130-153. https://doi.org/10.1108/SEF-01-2018-0013

Darrat, A. F., Gray, S., Park, J. C., \& Wu, Y. (2016). Corporate governance and bankruptcy risk. Journal of Accounting, Auditing \& Finance, 31, 163-202. https://doi.org/10.1177/0148558X14 560898

De Roeck, K., El Akremi, A., \& Swaen, V. (2016). Consistency matters! How and when does corporate social responsibility affect employees' organizational identification? Journal of Management Studies, 53, 1141-1168. https://doi.org/10.1111/joms.12216

Desender, K., \& Epure, M. (2015). Corporate governance and corporate social performance: Boards, ownership and institutions. Academy of Management Proceedings, 2015, 16433. https://doi. org/10.5465/ambpp.2015.16433abstract

Dorfleitner, G., Halbritter, G., \& Nguyen, M. (2015). Measuring the level and risk of corporate responsibility: An empirical comparison of different ESG rating approaches. Journal of Asset Management, 16, 450-466. https://doi.org/10.1057/jam.2015.31

Ducassy, I. (2013). Does corporate social responsibility pay off in times of crisis? An alternate perspective on the relationship between financial and corporate social performance. Corporate Social Responsibility and Environmental Management, 20, 157-167. https://doi.org/10.1002/csr.1282

Dyck, A., Lins, K. V., Roth, L., \& Wagner, H. F. (2019). Do institutional investors drive corporate social responsibility? International evidence. Journal of Financial Economics, 131, 693-714. https:// doi.org/10.1016/j.jfineco.2018.08.013

Edmans, A. (2011). Does the stock market fully value intangibles? Employee satisfaction and equity prices. Journal of Financial Economics, 101, 621-640. https://doi.org/10.1016/j.jfineco.2011. 03.021

El Ghoul, S., Guedhami, O., \& Kim, Y. (2017). Country-level institutions, firm value, and the role of corporate social responsibility initiatives. Journal of International Business Studies, 48, 360385. https://doi.org/10.1057/jibs.2016.4

Fabrizi, M., Mallin, C., \& Michelon, G. (2014). The role of CEO's personal incentives in driving corporate social responsibility. 
Journal of Business Ethics, 124, 311-326. https://doi.org/10.1007/ s10551-013-1864-2

Fernando, C. S., Sharfman, M. P., \& Uysal, V. B. (2017). Corporate environmental policy and shareholder value: Following the smart money. Journal of Financial and Quantitative Analysis, 52, 2023 2051. https://doi.org/10.1017/S0022109017000680

Ferrell, A., Liang, H., \& Renneboog, L. (2016). Socially responsible firms. Journal of Financial Economics, 122, 585-606. https://doi. org/10.1016/j.jfineco.2015.12.003

Fich, E. M., \& Slezak, S. L. (2008). Can corporate governance save distressed firms from bankruptcy? An empirical analysis. Review of Quantitative Finance and Accounting, 30, 225-251. https://doi. org/10.1007/s11156-007-0048-5

Flammer, C. (2015). Does corporate social responsibility lead to superior financial performance? A regression discontinuity approach. Management Science, 61, 2549-2568. https://doi.org/10.1287/ mnsc. 2014.2038

Flammer, C., \& Kacperczyk, A. (2016). The impact of stakeholder orientation on innovation: Evidence from a natural experiment. Management Science, 62, 1982-2001. https://doi.org/10.1287/ mnsc. 2015.2229

Freeman, R. E. (1984). Strategic management: A stakeholder approach. Pitman.

Friede, G., Busch, T., \& Bassen, A. (2015). ESG and financial performance: Aggregated evidence from more than 2000 empirical studies. Journal of Sustainable Finance \& Investment, 5, 210-233. https://doi.org/10.1080/20430795.2015.1118917

Friedman, M. (1970, September 13). The social responsibility of business is to increase its profits. The New York Times Magazine. Retrieved May 22, 2021 from https://www.nytimes.com/1970/ 09/13/archives/article-15-no-title.html.

Garcia, A. S., Mendes-Da-Silva, W., \& Orsato, R. J. (2017). Sensitive industries produce better ESG performance: Evidence from emerging markets. Journal of Cleaner Production, 150, 135-147. https://doi.org/10.1016/j.jclepro.2017.02.180

Garcia-Castro, R., Ariño, M. A., \& Canela, M. A. (2010). Does social performance really lead to financial performance? Accounting for endogeneity. Journal of Business Ethics, 92, 107-126. https://doi. org/10.1007/s10551-009-0143-8

Godfrey, P. C., Merrill, C. B., \& Hansen, J. M. (2009). The relationship between corporate social responsibility and shareholder value: An empirical test of the risk management hypothesis. Strategic Management Journal, 30, 425-445. https://doi.org/10.1002/smj.750

Harrison, J. S., \& Berman, S. L. (2016). Corporate social performance and economic cycles. Journal of Business Ethics, 138, 279-294. https://doi.org/10.1007/s10551-015-2646-9

Hofmann, H., Schleper, M. C., \& Blome, C. (2018). Conflict minerals and supply chain due diligence: An exploratory study of multi-tier supply chains. Journal of Business Ethics, 147, 115-141. https:// doi.org/10.1007/s10551-015-2963-z

Ioannou, I., \& Serafeim, G. (2011). The consequences of mandatory corporate sustainability reporting (Harvard Business School Research Working Paper 11-100.

Ioannou, I., \& Serafeim, G. (2012). What drives corporate social performance? The role of nation-level institutions. Journal of International Business Studies, 43, 834-864. https://doi.org/10.1057/ jibs.2012.26

James, S. D. (2016). Strategic bankruptcy: A stakeholder management perspective. Journal of Business Research, 69, 492-499. https:// doi.org/10.1016/j.jbusres.2015.05.006

Jensen, M. C., \& Meckling, W. H. (1976). Theory of the firm: Managerial behavior, agency costs and ownership structure. Journal of Financial Economics, 3, 305-360. https://doi.org/10.1016/0304405X(76)90026-X
Jostarndt, P., \& Sautner, Z. (2008). Financial distress, corporate control, and management turnover. Journal of Banking \& Finance, 32, 2188-2204. https://doi.org/10.1016/j.jbankfin.2007.12.040

Kemper, A., \& Martin, R. L. (2010). After the fall: The global financial crisis as a test of corporate social responsibility theories. European Management Review, 7, 229-239. https://doi.org/10.1057/ emr.2010.18

Kim, Y., Li, H., \& Li, S. (2014). Corporate social responsibility and stock price crash risk. Journal of Banking \& Finance, 43, 1-13. https://doi.org/10.1016/j.jbankfin.2014.02.013

Kim, Y., Park, M. S., \& Wier, B. (2012). Is earnings quality associated with corporate social responsibility? The Accounting Review, 87, 761-796. https://doi.org/10.2308/accr-10209

Köhler, P., \& Landgraf, R. (2020, July 14). Blackrock greift beim Klimaschutz durch. Handelsblatt. Retrieved May 22, 2021 from https://www.handelsblatt.com/finanzen/banken-versicherungen/ banken/esg-kriterien-blackrock-greift-beim-klimaschutz-durch/ 26000222.html.

Lee, D. D., \& Faff, R. W. (2009). Corporate sustainability performance and idiosyncratic risk: A global perspective. Financial Review, 44, 213-237. https://doi.org/10.1111/j.1540-6288.2009.00216.x

Liang, H., \& Renneboog, L. (2017). On the foundations of corporate social responsibility. The Journal of Finance, 72, 853-910. https:// doi.org/10.1111/jofi.12487

Lin, K. C., \& Dong, X. (2018). Corporate social responsibility engagement of financially distressed firms and their bankruptcy likelihood. Advances in Accounting, 43, 32-45. https://doi.org/10. 1016/j.adiac.2018.08.001

Lins, K. V., Servaes, H., \& Tamayo, A. (2017). Social capital, trust, and firm performance: The value of corporate social responsibility during the financial crisis. The Journal of Finance, 72, 17851824. https://doi.org/10.1111/jofi.12505

Lucas, R. E. (1980). Methods and problems in business cycle theory. Journal of Money, Credit and Banking, 12, 696. https://doi.org/ $10.2307 / 1992030$

Margolis, J. D., \& Walsh, J. P. (2003). Misery loves companies: Rethinking social initiatives by business. Administrative Science Quarterly, 48, 268. https://doi.org/10.2307/3556659

McGrattan, E. R., \& Prescott, E. C. (2014). A reassessment of real business cycle theory. American Economic Review, 104, 177-182. https://doi.org/10.1257/aer.104.5.177

McWilliams, A., \& Siegel, D. (2001). Corporate social responsibility: A theory of the firm perspective. Academy of Management Review, 26, 117. https://doi.org/10.2307/259398

Meyer, K. E. (2004). Stakeholder influence and radical change: A coordination game perspective. Asia Pacific Journal of Management, 21, 235-253. https://doi.org/10.1023/B:APJM.0000024085. 96792.44

Mooney, A., Miller, J., \& Smith, P. (2020, February 6). BlackRock rebukes Siemens on its environmental record. Financial Times. Retrieved May 22, 2021 from https://www.ft.com/content/92512 bcc-48b3-11ea-aee2-9ddbdc86190d.

NBER. (2021). Retrieved May 22, 2021 from https://www.nber.org/ research/business-cycle-dating.

Nigam, N., \& Boughanmi, A. (2017). Can innovative reforms and practices efficiently resolve financial distress? Journal of Cleaner Production, 140, 1860-1871. https://doi.org/10.1016/j.jclepro.2016. 09.190

Orlitzky, M. (2015). The politics of corporate social responsibility or: Why Milton Friedman has been right all along. Annals in Social Responsibility, 1, 5-29. https://doi.org/10.1108/ ASR-06-2015-0004

Parker, S., Peters, G. F., \& Turetsky, H. F. (2002). Corporate governance and corporate failure: A survival analysis. Corporate 
Governance: THe International Journal of Business in Society, 2, 4-12. https://doi.org/10.1108/14720700210430298

Platt, H., \& Platt, M. (2012). Corporate board attributes and bankruptcy. Journal of Business Research, 65, 1139-1143. https://doi. org/10.1016/j.jbusres.2011.08.003

Refinitiv. (2021). Retrieved May 22, 2021 from https://www.refin itiv.com/en/financial-data/company-data/esg-research-data\# find-out-more.

Richardson, G., Lanis, R., \& Taylor, G. (2015). Financial distress, outside directors and corporate tax aggressiveness spanning the global financial crisis: An empirical analysis. Journal of Banking \& Finance, 52, 112-129. https://doi.org/10.1016/j.jbankfin. 2014.11.013

Robinson, D., Robinson, M., \& Sisneros, C. (2012). Bankruptcy outcomes: Does the board matter? Advances in Accounting, 28 , 270-278. https://doi.org/10.1016/j.adiac.2012.06.003

Scheidler, S., Edinger-Schons, L. M., Spanjol, J., \& Wieseke, J. (2019). Scrooge posing as Mother Teresa: How hypocritical social responsibility strategies hurt employees and firms. Journal of Business Ethics, 157, 339-358. https://doi.org/10.1007/s10551-018-3788-3

Servaes, H., \& Tamayo, A. (2013). The impact of corporate social responsibility on firm value: The role of customer awareness. Management Science, 59, 1045-1061. https://doi.org/10.1287/ mnsc. 1120.1630
Sudarsanam, S., \& Lai, J. (2001). Corporate financial distress and turnaround strategies: An empirical analysis. British Journal of Management, 12, 183-199. https://doi.org/10.1111/1467-8551.00193

Vishwanathan, P., van Oosterhout, H., Heugens, P. P. M. A. R., Duran, P., \& Essen, M. (2020). Strategic CSR: A concept building metaanalysis. Journal of Management Studies, 57, 314-350. https:// doi.org/10.1111/joms.12514

Whitaker, R. B. (1999). The early stages of financial distress. Journal of Economics and Finance, 23, 123-132. https://doi.org/10.1007/ BF02745946

Wruck, K. H. (1990). Financial distress, reorganization, and organizational efficiency. Journal of Financial Economics, 27, 419-444. https://doi.org/10.1016/0304-405X(90)90063-6

Zhao, X., \& Murrell, A. J. (2016). Revisiting the corporate social performance-financial performance link: A replication of Waddock and Graves. Strategic Management Journal, 37, 2378-2388. https://doi.org/10.1002/smj.2579

Publisher's Note Springer Nature remains neutral with regard to jurisdictional claims in published maps and institutional affiliations. 